\title{
KA TIRITIRIA - SHARING THE SEEDS OF 'HOPE' (HOLD ON PAIN ENDS)
}

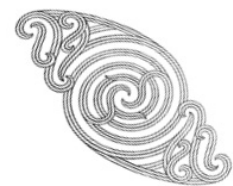

\author{
Kevin Hollingsworth, Vicki Rangitautehanga Murray, \\ Goldie Mihinui, Billy Mihinui, Tuihi Carre, Tiwana Taiatini, \\ Pauline Tai, and Edith Te Papa
}

\section{WHAKAPAPA KŌRERO AND INTRODUCTION}

Ko Kevin Hollingsworth taku ingoa. While my whakapapa is from the North, I was born and raised among Te Arawa. In my own journey of self-discovery, I developed a passion for working with whānau who have mental health and addiction issues. Brought up in a home with strong tikanga principles, my upbringing supports the way I work with whānau. As a registered Māori Clinical Practitioner, I witnessed first-hand there was no support in the community for whānau indirectly and directly affected by methamphetamine. As a result, in 2017, I formed the Mana Enhancing Group, a model care to help awhi (embrace) tangata whaiora and their whānau to feel empowered by the outcome of psychotherapy as a treatment for their addiction and problematic behaviours.

As the roopu grew, those who attended regularly asked us to start up in the community, based in the local Church and Marae based. We did and gave birth to the Mana Enhancing STOP roopu. STOP is an acronym for Stop Taking Our People; that is taking them from us due to methamphetamine. Our processes are reviewed often as we embrace mātauranga Māori (knowledge) and holistic practices to help heal our whānau affected by the rising issue of methamphetamine addiction in Aotearoa.

To gain greater understanding, knowledge and skills to support their communities, the facilitators and whānau tautoko (supporters) of Mana Enhancing STOP enrolled in a New Zealand Certificate in Public Health and Health Promotion Suicide Intervention and Prevention programme. The wānanga based course delivered by Te P $\bar{u}$ Wānanga o Anamata, the Tūhoe PTE (private training establisment), is based in Tāneatua. The roopu orations are reproduced with permission from the individuals, who also desired the use of their names. Each kōrero (contribution) emerges from the Mana Enhancing STOP practice and are covered by Otago Polytechnic Ethics. In addition to this formal process, the words of the roopu are protected by the guardianship of the Mana Enhancing STOP leaders and convenors and held within a space of great reverence.

\section{KA TIRITIRIA: OUR VOICES}

Ka tiritiria speaks to the seeds of hope shared with everyone who enters the Mana Enhancing STOP community. A harmony of expressions of Māori dimensions of resilience echo through personal encounters from within.

Te reo taki, Kevin Hollingsworth (the lead speaker/author) has presented a whakapapa of the emergence of the Mana Enhancing STOP movement. Te reo mirimiri, Vicki Murray, te kaiako (the course tutor) pens this brief introduction to the chorus of voices weaving the article title, te koha körero (gift of words) from her students and selected Shakespearian passages together. In Goldie Mihinui's rendition te reo tuatahi (the first refrain) her 
soul is laid bare as a survivor indirectly affected by meth. Nga reo tuarua (the second compilation of voices) are reflections on aspects of practice by Billy Mihinui and Tuihi Carre. Insights are woven through the application of mana, mauri and tapu followed by an awareness of noa within te porowhita (sacred circle). Tiwana Taiatini goes on to explain the implementation of the rākau, a motif fostering the sense of safety and agency to those sharing in the porowhita. Pauline Tai along with Billy flow on as ngā reo tuatoru (the third accounts) giving a slant on kōhatu as milestones of achievement. He kupu aroha hei kōrero whakakapi (the fourth and fifth unflinching raw recollections) by Edith Te Papa and Billy are inspiring finales to this compilation.

\section{VICKI AND “OTHELLO”}

Once the scripts were gathered together, the moving, normally muted lived experiences portrayed by Goldie, Edith and Billy in concert with the main theme of the course whakamōmori (suicide prevention and intervention) brought parallel iconic theatrical widsoms from the play Othello to mind. In 2016, Regan Taylor saw parallels with Othello and Māori experience in SolOthello, produced in Auckland using Te Mata Kokako o Rehia (masks) (McKee, 2016). The theme of human deterioration is at its heart, and, here, I reapply the mask.

Several citations from William Shakespeare's 1603 tragedy (referenced by act and scene only) resound within these three, real life contexts:

Oh, beware, my lord, of jealousy!

It is the green-eyed monster which doth mock

The meat it feeds on (III.iii.).

Goldie's story: He was overcome with jealousy (line 17).

Men in rage strike those that wish them bes. (II.iii.).

Goldie's story: While in his meth fueled rages I got smashed, punched in the head, my body pummeled, I was dragged about, almost choked to death, a knife held to my chest (lines 18-19.)

[She] loved me for the dangers I had passed (I.iii.).

Edith about Billy: of her love of bad boys (line 5).

I saw 't not, thought it not, it harmed not me (III.iii.).

Edith: at the beginning of their relationship not knowing Billy used, and later not knowing what whānau indirectly affected by meth were going through (lines 10 \& 48).

For I will wear my heart upon my sleeve, for daws to pick at; I am not what I am (I.i).

Billy going clean: Asking for help meant to open up, to be vulnerable; in search of his true self.

Too hideous to be shown, it is deceitful and evil

I am not what I am (III.iii).

lago the deceitful and manipulative antagonist - in this context is the motif for methamphetamine.

Shakespeare's drama ends after the Moor smothers Desdemona, his wife, and then kills himself when he realises she was innocent and he had been duped by his trusted friend, lago.

Then must you speak

Of one that loved not wisely but too well (V.ii.).

Billy sold his soul to meth, and on the pipe he had no consideration of others wreaking havoc upon all and sundry. 


\section{TE REO TUATAHI: GOLDIE'S STORY}

I am Goldie, as a young child I was nurtured by loving parents

I was a happy outgoing girl

One of the youngest of eight

My life was simple, fun and carefree

I lost my pāpā my pou and my rock to cancer when I was 12

Soon after I met my first love, Arthur

He was a quiet fun and caring young man

I moved in with him. Life was beautiful and sweet.

Our first pepe arrived when we were 16.

At 19 he became a patched member and things changed

His staunchness came out, he was ruthless, his behaviour was out the gate

He began using meth

He became controlling not letting me go out

No socialising, no friends, he took away my freedom

I was a prisoner in our home, locked in the room.

Then the beatings started

He was overcome with jealousy

While in his meth fueled rages I got smashed, punched in the head, my body pummeled, I was dragged about, almost choked to death, a knife held to my chest

The bruises were hidden but I was so mamae I couldn't move or sleep

The verbal and physical abuse grew worse as the meth took over him

This was the darkest time for me, and our four tamariki

Who heard, felt, and lived through the violence inflicted on me

They huddled together silenced by terror, their little bodies trembling with fear and anguish

I lost my mana, my mauri was broken and my tapu was shattered!

The demon drug meth, turned my husband into something, someone else

My mind screamed: Who is this person? Why is he doing this?

I never thought I would escape that bleak joyless place

Suicidal thoughts filled my heart, my mind, my whole being

But who would take care of our babies?

What was this pitiful thing I had become?

Exhausted and sick of it all, I knew I had to get away

I had to leave him

I got the strength to seek help and am here today because of the support of my hāhi

I am fully committed to my faith, the love, encouraging words and scriptural advice give me comfort

Finally, one day after trying and failing again and again

He went in search of help and eventually found Mana Enhancing STOP roopu

He asked me to go too, to see that he was indeed working on getting clean

So, I went along to support him

And found that in the sacred circle

I was able to release my mamae to help me heal too

Our journey of recovery together continues today

Arthur and I now have a strong and open relationship

Where we work on everything as a couple, as a whānau. 
My 10 years of debilitating abuse and 18 years of surviving the indirect effects of meth have ended He wahine toa ahau aianei

I am 37 now and am a strong and vibrant woman

I am a wife, a māmā and a nanny

I am Goldie and this is my story.

\section{NGĀ REO TUARUA: MANA, MAURI, TAPU AND NOA}

Billy: At the beginning of each session, we explain mana, mauri and tapu, the three principles applied in our roopu porowhita. From my lived experience of active addiction, our connection to turangawaewae (our whenua, who we are as tangata, our identity) and culture as Māori is lost. This leads to a loss of mana. When people come seeking help, we begin their journey of recovery by seeking to regain their mana. Learning our connection to whenua, to hapu, iwi and each other through whakapapa is one of the first steps we take together. The mauri or life force of the speaker's words is aroused during the rākau kōrero. The rākau gives whānau the opportunity to speak their truth, their pain, their grief, shame, and hope for themselves and loved ones. As this space is tapu they can talk unrestrained to set aside all the guilt and blame they carry knowing it will be acknowledged without judgement.

Tuihi: Tapu is the sacred space we preserve. What we hear in the porowhita, what we say, and who we see is totally confidential. It is a safe place for whānau to be able to share their truth knowing their kōrero stays within the circle. Noa also sits with mana, mauri, and tapu, a holistic practice in our roopu sessions. When whānau arrive, they are offered a hot drink and something to eat, this creates a setting back to normality, or noa.

Almost everyone who attends is struggling to cope with meth addiction or the behaviours of loved ones who are addicted, we acknowledge their own mana, mauri and tapu. These are conveyed within their thoughts and feelings aired in the porowhita. Whānau disclose deep seated feelings, so real and raw that these can trigger others in the circle. Therefore, it is important tikanga in the rākau kōrero is upheld. Once the rākau is handed to the next person, mana and mauri are in a state of hiatus, whereby tapu no longer exists, and noa presides.

Karakia is performed to open and close hui or work within the sacred circle. Post hui, there is time for whānau to mingle and chat informally with others in attendance over a cuppa. The importance this interlude is to ensure whānau are at ease before they leave us.

Vicki: Noa is embraced within the domains of Papatuānuku, the female element. Noa is the constant companion to tapu, or the male element assumed within the realms of Ranginui. The continuum or presence of both tapu and noa is essential in maintaining balance (Durie, 200I; Murray, 2012; Shirres, 1982).

\section{RĀKAU KŌRERO}

Billy: My aunty, Honey Thrupp gifted us this rākau to use in the porowhita. She said to me, "The blue, black, red and yellow colours represent the gangs you will work with. White is the peace you will bring to their lives and green is for growth my boy, which is something you have done. I added the cross for protection."

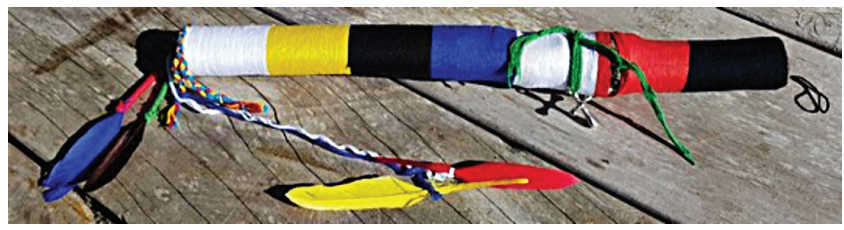

Tiwana: The rākau is introduced to our meetings as the talking stick. The person who holds the rākau is the only one that speaks. When the speaker is finished the rākau is placed on Papatuānuku (on the 
ground) in front of the speaker, as an indication to the facilitator to provide feedback. If the rākau stays on the ground when the facilitator has finished, the speaker is inviting more feed-back from the roopu. Once the speaker picks up the rākau all kōrero stops. The rākau is then passed on to the next person in the circle. The rākau kōrero maintains the mana, the mauri, and tapu within the roopu and specifically with the speaker.

\section{NGĀ REO TUATORU: KŌHATU}

Pauline: We have implemented kōhatu (coloured river rocks) milestones into our programme. Milestones are measurable targets our whānau in recovery can strive toward. The kōhatu are physical and spiritual tohu they receive at different stages of their recovery. Once achieved, whānau have a sense of accomplishment and look forward to achieving the next milestone. We have a 3-month (orange kōhatu), a 6-month (red kōhatu), and a I-year (greenstone/pounamu) milestone. With each kōhatu, whānau also receive a whakataukT. The kōhatu are from Papatūannuku, and if whānau have a slip they give back their kōhatu. We return it to the land, and they are required to start again.

Billy: In our roopu, the kawa (process) is slightly different to our whānau in Te Arawa. When whānau relapse, they become the kaupapa (focus) of the meeting. We do this to give them a sense of community because they are usually whakama (ashamed) and it takes a lot of courage to come back into the roopu when they slip. Our role is to support them by going to the river where we perform cleansing rituals. The kōhatu are then returned to the river. We then reset their plan to overcome their obstacles to recovery.

I choose each kōhatu carefully, looking for certain shapes and sizes. It's more of a feeling, a wairua (intuitive and spiritual knowing). The kōhatu tell me which ones to take. The milestone journey begins when the whannau walk in the door even if they have been clean before they attend. The orange kōhatu is to acknowledge them slowing down, where they ask themselves, "Am I in or am I out?" The orange kōhatu is bigger because the beginning is the hardest part of the recovery journey. This is when they are challenged the most and when whannau are most likely to slip. The red kōhatu means whānau have made the decision to stop.

\section{TE REO TUAWHĀ: EDITH - HOPE}

I was never going to be a stay-at-home wife

I sure was never going to be controlled by any man

Not me!

But that was before Billy

I loved bad boys

And I fell for the biggest gangster bad boy in town

Billy who made me feel like I was the only one on this earth

Billy who would tell me I was so beautiful

Billy who loved that I was wild and couldn't be tamed

I didn't know it at the time but Billy was using

Then he began dealing meth too

Over time it got worse and worse

He left me for other women

His desire to use meth was stronger than his will to live

Billy's addictions were using meth, dealing meth and women

My addiction was Billy

I found myself in gangs to support his use

I became a dealer 
It started with tinnies, synies and then meth

I used Billy as a front

Police with search warrants

Other gangs chasing Billy

And buyers came to our place at all hours of the day

And under the cover of the night cos meth never sleeps

In the 16 years of being indirectly affected by Billy's addictions

I never took any of his money

I never touched the pipe

I would look at Billy's behaviour and say "F..., he's out the gate."

And decided "No way, that's not for me!"

Dealing became my next addiction

Cos I loved getting away with stuff

I was attracted to and then got hooked on the money

I grew a reputation and status

Billy was jealous of my dealing

For years I would send them to Billy

Everyone knew where-ever Billy was, there would be meth

But then people started realising I was the dealer

When that happened

I stopped going out because people I was supplying to would come and find me

I kept on working my other jobs even though I had lots of ready cash

The jobs and Billy were my cover

I was really good at dealing

I never ever thought I had a problem

I was a huge enabler of his addiction

I wanted him off meth but I loved him so much

I would shower him with every-thing

It was a chaotic, intense and poisonous relationship

All we were doing was out chasing meth

I didn't care what it did to others because I didn't see the struggles their whānau were going through

Even though I lost touch with my tamariki, my mokopuna, my whānau and my hapu

Being left for other women nearly broke me

I asked why he couldn't stick with me?

I would do crazy things when I found him with other women

When I started thinking about exposing him and then taking his life, their lives

I knew I was going over the edge

So, I reached out for help

I went on a program for women like me who were in unhealthy relationships

I learned to love myself again, found peace and reconnected with my friends

Joy and laughter returned and I began working to gain back my mana

When Billy saw me change, he started talking about going clean

My whānau told me, to help him I would have to stop dealing

For years I had prayed for Billy to go clean so I stopped and supported his journey of recovery

We are here today because when we were both in addiction

Even though it was such an ugly time especially when he picked up the pipe

I always held a slither of hope, remembering what Billy was like when we first fell in love 
I wanted that Billy back

I am Edith and I got my Billy back

Today my focus is on being a wife, a māmā, a kuia, a sister, a daughter, an aunty, and a cousin again

Living a clean life

I am a co-facilitator in the Mana Enhancing STOP roopu for Tāneatua and Ruātoki

Alongside Billy, we help our community get clean

In the sacred circle, I share my story because the truth needs to be told and it helps me heal

Parts of that life still hurt, our behaviours harmed a lot of people, particularly our tamariki

We know there are many others like us who will need support getting out too

In the beginning it was hard because people were still coming up and saying

"Are you fullas still on?"

I had to say, "I don't do that anymore" and invite them in for a cup of tea

It's not easy because recovery is new to us

We are trying to learn as much as we can to help ourselves help others

The road to recovery is as uncertain as the road through addiction

I still get triggered by those who relapse because I know it means there's more pain ahead for them

Billy was the face of meth during his addiction

Today Billy is the face of recovery

I am in the background, the machine managing and supporting Billy and our roopu

Our recovery is a clear message to the community, to our whānau

that it is possible to overcome addiction

A member of the meth community told us

"Well, if I ever want to go clean, I'll come to see you two."

Me, Billy and our Mana Enhancing STOP roopu are here to give people HOPE

We tell whānau HOPE means Hold on Pain Ends

Ko Edith ahau, tēnei taku kōrero.

\section{D) TE REO TUARIMA: BILLY - WHY I DECIDED TO GO 'CLEAN'}

My wife stepped away from me

I was broken, my body was shattered, I was so tired of being tired - of not feeling loved

I was in a really dark space, the little fella on my shoulder his voice was so loud

I couldn't see any other way out except death

I was fried when I saw my wife from a distance

I wondered what she was up to her face was glowing

I hadn't seen her big bright beautiful smile in a long time

I was still high at her graduation but could see she was full of life and I envied she could be that happy

without me

Resentful I screamed, "You left me to rot in the gutter."

I broke down, I had P on me, a pipe on me, I said to her I'm done babe I need help!

She said you are not going to like it but you have to go back to rehab

In my darkness I was sick of being sad, lonely

I still wanted to be on this earth for my moko, for my son

The shit I used to put them through was scary

My poor boy must live with the consequences of my behaviours

I know now, if you make the change, they make the change 
I tried buying love, that didn't work, you got to earn the love

I would sit in my car asking the Atua, "Is this all I'm here for? Is this it? But this is dumb."

I was constantly hurting Edith. I had all the money and anything I wanted but I was so lonely

I would rather be poor but have my wife by my side, wake up with her every day

It hurts, it hurts in a good way. I promised my wife, "You don't have to worry anymore."

I have to settle my mind and heart to live a different life. I see better now, am more content

To be a better version of myself, I had to be selfish to get clean, and then came back for my whānau

The Mana Enhancing STOP roopu saved me, I needed the support, I still do

l'd rather be here taking on life's challenges without substance

Sometimes I get angry because this mahi still takes me away from my boy

My wife has invested into this kaupapa fully

It takes so much of our time

The biggest lesson is not taking it home, but we tell people we are a 24-hour service

This space is not made by funding or by people with letters before and after their names

But by whānau loving whānau.

\section{TE REO WHAKAKAPI}

\section{Vicki: Final words}

I kiss'd thee ere I kill'd thee

No way but this

Killing myself, to die upon a kiss. (V.ii.)

Rather than closing with Othello's dying speech because the co-stars of the Mana Enhancing STOP roopu radiate an attitude of gratitude sharing the hopeful kiss of life;

instead the concluding proclamation is:

To mourn a mischief that is past and gone

Is the next way to draw new mischief on. (I.iii.)

Pauline: I've no regrets, what is done is done, we just get on with the mahi.

Ka tiritiria, ka poupoua ki a Papatūānuku, ki te whei ao ki te ao mārama (Murray, 2017; Nepe, 1991), is a closing edict in karakia to declare that the seeds of knowledge have been sown into mother earth to blossom and grow in her loving embrace. This collection of voices is distributed (in Scope Work-Based Learning 2) and planted into the hearts and minds of the reader, to bring light and hope into the lives of those seeking a pathway out of the darkness. 


\section{S) TE TIRA KŌRERORERO: BIOGRAPHIES}

Ko Kevin Hollingsworth ahau. I am the lead author and currently studying a Master of Professional Practice through Otago Capable NZ, Advance Practitioner Inquiry. My thesis topic is "Mana Enhancing Practices help to inform Therapeutic Communities" from a Te Ao Māori World View, looking at a whānau, hapū, iwi approach to community sobriety and exploring how whānau can heal from methamphetamine addiction.

Email: kevinholly9@gmail.com

Ko Rangipoua me Urukaraka ngā Maunga, Ko Waioira me Ōpurana ngā Awa, Ko Ōmaio me Ngāhina ngā Marae, Ko te Whānau-a-Apanui me Tūhoe ngā Iwi, Ko Josephine Kotiro Mihinui toku ingoa. My whānau and friends know me as Goldie. My role in the roopu is to support whānau.

Ko Maunga Pohatu te Maunga, Ko Mataatua te waka, Ko Tūhoe te iwi, Ko Billy Mihinui ahau. I come from a I6-year addiction with pourakino. I destroyed homes, took whānau away from whānau. I stood over and hurt people. I am now almost 2-years clean and happy in my new skin. I facilitate the Mana Enhancing STOP in Tāneatua.

He uri nō Ngāti Awa, Tūwharetoa, Te Arawa me Tūhoe. Ko Tuihi Carre taku ingoa. I am the secretary for the Mana Enhancing STOP Tāneatua and Ruātoki.

Tarakiha te maunga, Ōpepe te awa, Ōpape te marae, Whakatōhea te iwi. My name is Steven Taiatini, I am 43. I have been in the gang since I was I5. I have been in and out of addiction since I was eight and have also been in and out of jail. Today I am the leader of a gang and a facilitator in Mana Enhancing Stop to support whānau going through addiction mainly with meth. I uphold this stance in my chapter because I have lived through the destruction and have seen what meth does to our whānau.

My name is Pauline Tai, I hail from Te Whakatōhea and Te Whānau $\bar{a}$ Apanui. I am the General Manager and a facilitator of Mana Enhancing STOP Te Arawa and Te Whare Rauora. I survived a 19-year addiction to meth and have been clean for three years. I am a graduate of Te Whare Oranga Ngākau rehabilitation centre. I learned how destructive my addiction behaviours were to everyone I touched. I went from dealer to healer.

Ko ōku pae Mauna: Ko Taiarahia me Tahūhū o Haokitaha. Ko ōku Marae: Te Totara me Papakaina. Ko ōku Hapu: Te Urewera me Nāti Koura. Ko Ōhinemataroa te Awa. Ko Tūhoe te Iwi. Ko Ruātoki te Kaina noho. Ko Edith Te Rangi Te Papa ahau.

Ko Vicki Rangitautehanga Murray ahau, he uri nō Ngāti Pūkeko me Ngāti Awa. Further to my role as the tutor on the Anamata course, I am a learner on the Doctor of Professional Practice with Te Kura Matatini ki Otago.

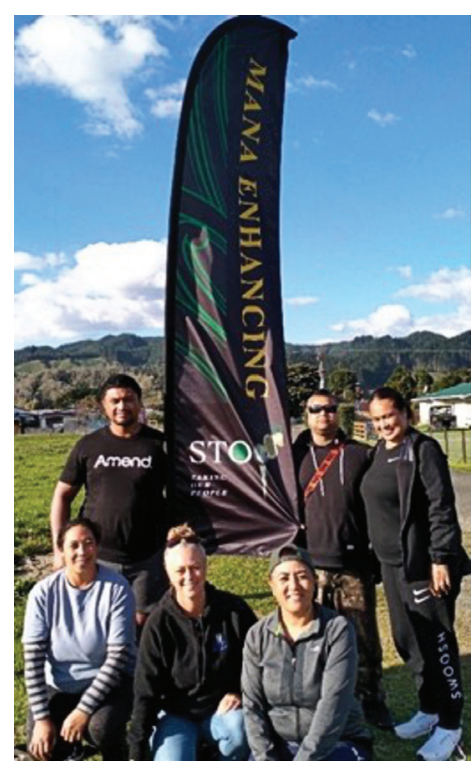

Billy Mihinui, Tiwana Taiatini, Pauline Tai Goldie Mihinui, Tuihi Carre, Edith Te Papa In Tāneatua, May 2021. 


\section{REFERENCES}

Durie, M. (200I). Mauri ora the Dynamics of Māori Health. Oxford University Press.

McKee, H. (2016, June 10). Shakespeare gets a Maori twist in SolOthello. Stuff. https://www.stuff.co.nz/entertainment/stageand-theatre/80922072/shakespeare-gets-a-maori-twist-in-solothello

Murray, V. (2012). Hoki ki tōu maunga kia purea ai koe ki ngā hau o Tāwhirimātea - A tangata whenua model of supervision. Aotearoa New Zealand Social Work Journal Te Komako, 24(3-4), 3-II. https://doi.org/I0.1 II57/anzswj-vol24iss3-4idI 02

Murray, V. R. (2017). Hoki ki tōu maunga kia purea ai koe ki ngā hau o Tāwhirimātea - A tangata whenua model of supervision. Unpublished Thesis for a Masters in Social \& Welfare at the University of Otago.

Nepe, T. (1991). E Hao E T nei Reanga Te Toi Huarewa Tipuna. Unpublished M.A. Thesis, Auckland University, Auckland. Shakespeare, W. (1603/2004). Othello, The Moor of Venice. Schuster Publishers.

Shirres, M. P. (1982). Tapu. Journal of the Polynesian Society, 91 (I), 29-52. 